\title{
INNOVATIVE CHEMISTRY LEARNING MODEL: IMPROVING THE CRITICAL THINKING SKILL AND SELF-EFFICACY OF PRE-SERVICE CHEMISTRY TEACHERS
}

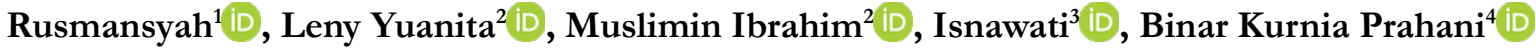 \\ ${ }^{1}$ Lambung Mangkurat University (Indonesia) \\ ${ }^{2}$ State University of Surabaya (Indonesia) \\ ${ }^{3}$ State Junior High School 6 of Banjarmasin (Indonesia) \\ ${ }^{4}$ Sunan Ampel State Islamic University (Indonesia) \\ rusmansyah_kimia@unlam.ac.id, lenyyuanita@unesa.ac.id,musliminibrabim@unesa.ac.id, isnawati53@gmail.com, \\ binarprahani@gmail.com
}

Received September 2018

Accepted November 2018

\section{Abstract}

Pre-service chemistry teachers should have the $21^{\text {st }}$ century competence such as critical thinking skill. Unfortunately, the critical thinking skill dan self-efficacy level of Indonesian pre-service chemistry teachers is still low. Problem Based Learning (PBL) model and Inquiry model have been implemented widely to improve the critical thinking skills and self-efficacy of pre-service chemistry teachers; however, weaknesses were found such as the need to improve self-efficacy and investigation process based on science process skill. Therefore, innovation was created to develop Scientific Critical Thinking (SCT) Learning Model based on strengths and weaknesses of PBL model and Inquiry model. This innovation was also supported by theories and empirical study. This study serves as preliminary study in the process of SCT learning model development to improve the critical thinking skills and self-efficacy of pre-service chemistry teachers. This study covers need analysis, literature review, and field survey. Result shows that the innovation can stand as the basis of hypothetic SCT learning model development. SCT learning model syntax covers: student orientation, scientific activity, presentation of scientific activity result, critical thinking task completion; and evaluation. Hypothetic SCT learning model should be tested to fulfill the validity, practicality, and effectiveness aspects to improve the critical thinking skills and self-efficacy of preservice chemistry teachers.

Keywords - Critical thinking skills, Pre-service chemistry teachers, SCT, Self-efficacy.

\section{To cite this article:}

Rusmansyah, Yuanita, L., Ibrahim, M., Isnawati, Prahani, B.K. (2019). Innovative chemistry learning model: Improving the critical thinking skill and self-efficacy of pre-service chemistry teachers. Journal of Technology and Science Education, 9(1), 59-76. https://doi.org/10.3926/jotse.555 


\section{Introduction}

The $21^{\text {st }}$ century competency framework becomes a foothold in the development of the Indonesian National Qualification Framework. The Indonesian National Qualification Framework (Kerangka Kualifikasi Nasional Indonesia, KKNI) is a skeleton of competency qualification that can pair, equalize and integrate the field of education and the field of job training and working experience in the framework of providing job competence recognition that is in accordance with the working structure of various sectors. One of the demands on level 6 (Bachelor / Diploma-4) is that students have to be able to apply their field of expertise and utilize Science and Technology in their field to solve problems and able to adapt to the situation they face (Perpres, 2012).

The theme of the Indonesian National Qualification Framework development is to produce productive, creative, innovative and affective students through strengthening attitudes, skills and integrated knowledge. To achieve the theme, learning process needs to support creativity that emphasizes personal experience through observing, asking, reasoning, trying, problems solving, and working in groups. Problem-solving skills and critical thinking skills are inseparable whole (Jatmiko, Prahani, Supardi, Wicaksono, Erlina, Pandiangan et al., 2018; Prahani, Suprapto, Suliyanah, Lestari, Jauhariyah, Admoko et al., 2018; Suyidno, Nur, Yuanita, Prahani \& Jatmiko, 2018). Therefore, chemistry learning in universities should pay attention and emphasize the chemistry learning that can improve critical thinking skills in solving the problems they face.

Chemistry is one branch of natural science. Based on global and historical views, all aspects of daily life such as food, drink, clothing, medicine, housing, vehicles, and many others are related to chemistry. Chemistry contributes in helping people solve complex life problems. In fact, it is found that many students study chemistry not because they are interested and then they have no understanding after studying chemistry (Alkan, 2016; Tarhan \& Sesen, 2013; Scott, 2013). Educators are required to present meaningful chemistry learning so students are interested in learning it as a provision to face the global era competition.

Pre-service chemistry teacher must have superior competence in the globalization era competition with various $21^{\text {st }}$ century skills; one of them is critical thinking skills. If critical thinking skills are not well developed by pre-service chemistry teachers, it will be difficult for them to face competition in the $21^{\text {st }}$ century. Research results (Atabaki, Keshtiaray \& Yarmohammadian, 2015; Birgili, 2015; Kalelioğlu \& Gülbahar, 2014; Kivunja, 2015) indicates that learning and assessment of critical thinking skills is needed and driven by the needs of students at the college level and working environment. Therefore, educators are required to improve their critical thinking skills of pre-service chemistry teacher in Indonesia.

The result of preliminary study by Rusmansyah (2016) toward Chemistry students in FKIP University of Lambung Mangkurat Banjarmasin who follow Chemistry School 1 course showed that students' critical thinking skills are still low $(25.57 \%)$. In general, 72 students still classified as incapable on critical thinking. The ability to analyze argument (31.83\%), identify assumption (60.35\%), ask and answer question $(19.48 \%)$, decide action $(15.91 \%)$ and induce $(1.04 \%)$. It indicates that the chemistry students' critical thinking is still low.

The results of interviews and observations on several students and lecturers revealed 1) the limited time for lecturers to develop learning models and tools that emphasize critical thinking skills especially for pre-service chemistry teachers; 2) students have difficulties in using science process skills in investigation activities; and 3) students have difficulties to complete the advanced tasks as a form of deepening and application of the material that was obtained from the learning activities. The results of these preliminary studies indicate a need for a chemistry learning model that emphasizes critical thinking and science process skills according to the character of the pre-service chemistry teacher students in Indonesia.

Self-efficacy is included in the 2015 PISA assessment. It is considered important to be measured because positive self-efficacy is closely related to motivation, learning behavior, future general expectations and learners' performance (OECD, 2015). Self-efficacy is a predictor of entering college in each domain. 
Teachers' professional beliefs are also measured in PISA 2015, in this case are educators' self-efficacy in classroom management, providing instruction and maintaining positive relationships with learners. Educators will also be required to report their self-efficacy with regard to their science and teaching content (OECD, 2015). Self-efficacy has a direct positive effect on students' scientific attitudes toward chemistry (Kurbanoglu \& Akim, 2010). The results of this study show that how important the selfefficacy to be trained and owned by pre-service chemistry teacher in Indonesia.

The results of Sasser (2014) study found that the structure of PBL is not a significant factor related to self-efficacy in teaching science. This is reinforced by Mataka and Kowalske (2015) findings, which stated that PBL is one of the student-centered learning strategies, in which students are given a big role in their own learning, so this role transfer may need more time for adaptation into the students' learning style. The results of the study on the above PBL and Inquiry model indicate the importance of innovation on the PBL and inquiry model to improve critical thinking skills and self-efficacy in chemistry learning

Each learning model has specific characteristics to teach particular learning outcomes, as well as the learning model the researchers developed in this study. Learning models that can improve critical thinking skills needed in the $21^{\text {st }}$ century and self-efficacy for pre-service chemistry teachers are not yet available, so this model is designed to fill the void.

Learning model that is developed through theoretical and empirical studies is expected to provide several benefits that can be obtained: 1) As an innovative learning model that not only trains critical thinking skills but also enables self-efficacy for pre-service chemistry teachers, 2) As an alternative of learning model that can be used to train critical thinking skills, 3) Availability of learning models that can bridge critical thinking skills needed in the $21^{\text {st }}$ century with self-efficacy for pre-service chemistry teachers, 4) Reference materials in the development of other learning models.

\section{Literature Review}

\subsection{The learning Model Characteristics}

The learning model is a frame of mind that guides someone to design and implement learning to help students to gain information, ideas, skills, values, ways of thinking, and the meaning of their expressions (Joyce, Weil \& Calhoun, 2009). The operational form of the learning model is the learning device. It indicates that each instructional model leads to design learning that helps learners achieve the learning objectives. According to Nieveen, McKenney, Gravemeijer and Van den Akker (2007) a good learning model must meet three conditions, they are: 1) validity: the validity of the model can be tested by testing the content validity and construct validity. Content validity is "there is a need for the intervention and its design is based on state-of-the-art (scientific) knowledge". (Nieveen, McKenney, Gravemeijer \& Van den Akker, 2007). Construct validity (construct validity) is "the intervention is 'logically' designed" (Nieveen, McKenney, Gravemeijer \& Van den Akker, 2007). 2) Practicality: realistic interventions (models) can be used in settings where the intervention has been designed and developed. Practicality refers to the extent to which users (or other experts) consider developed interventions to be used and preferred under normal conditions. Implementation of the model in the implementation of learning can be reviewed from the implementation of the syntax, the implementation of social systems, and the implementation of the reaction principle. 3) Effectiveness: the use of the intervention (model) produces the desired impact.

According to Joyce et al. (2009) a good learning model should have 5 (five) major components in the model, they are: 1) syntax, 2) social systems, 3) reaction principles, 4) support systems, and 5) instructional impacts and accompaniment impacts. According to Arends (2012) mentioned that at least four specific characteristics of the learning model that can be used to achieve the learning objectives are 1) the logical theoretical rationale of the design, 2) the learning objectives of the developed model, 3) the teaching behavior that is needed for the learning to be done, and 4) the learning environment needed to achieve the learning objectives. Based on the definitions and components that must exist in the learning model, it can be concluded that the learning model is a pattern used as a guide in designing and implementing learning, 
including learning objectives, phases (phases) in learning activities, learning environment, and the learning management in the classroom.

\subsection{Chemistry Learning in the Collage}

Chemistry is one of the natural science's branches and one of the most important sciences to be studied (Sirhan, 2007). Based on global and historical views, all aspects of daily life such as food, drink, clothing, medicine, housing, vehicles, etc. are related to chemistry. Chemistry contributes in helping people to solve complex life problems. Chemistry explains a lot about the phenomena that occur in everyday life, this makes the chemistry cannot be separated from life. To get the benefits of chemistry then the chemistry must be studied since in the junior level and then continued to high school and college level. Studying chemistry from different stages experiences different levels of knowledge tailored to the learner's educational stages. Chemistry in universities is related to the nature and life includes the material structure, composition, nature, changes and energy involved. According to Keenan, Kleinfelter and Wood (1984) chemistry studies the building (structure) of matter and changes experienced by matter in natural processes as well as in planned experiments. Through chemistry, we recognize the composition of substances and the use of chemicals, both natural and artificial, and recognize important processes in living things, including our own bodies.

This creates difficulties and misconceptions for students because they are mostly related to abstract concepts. The difficulties of studying chemistry in universities are caused by obstacles to support competencies in mastering concepts, on learning process and on students' environmental factors. The learning difficulties and misconceptions of this concept start from the middle school to college levels as mentioned by Tan and Treagust (1999). Chemistry concepts that become difficult and error in the learning is a core concept and a basis for further chemistry study or supporters of the natural science and other branches. In fact, it is found many students who study chemistry are not interested and have no understanding after studying chemistry (Alkan, 2016; Scott, 2013; Tarhan \& Sesen, 2013). The results of the research by Scott (2013) and Alkan (2016) indicated the need for further research to improve the inquiry-based learning model by developing learning models that can improve critical thinking skills and self-efficacy of pre-service chemistry teacher through laboratory investigation activities, in the process of learning chemistry in the classroom according to the demands of $21^{\text {st }}$ century skills and to compete in the world of work in the globalization era. Educators are required to present meaningful chemistry learning and the younger generation is interested in learning it as a provision to face the globalization era.

\subsection{Learning that Can Improve Critical Thinking Skills and Self-Efficacy}

Learning model is a comprehensive approach in planning a lesson with its attributes cover the theoretical framework, orientation to what is learned by students, as well as teaching procedures and structure (Arends, 2012). According to Joyce et al. (2009) suggest that the general characteristics of a learning model include syntax, social systems, reaction principles, support systems, instructional impacts, and companion impact.

\subsubsection{Problem Based Learning (PBL) Model}

In 1916 John Dewey gave a breakthrough in education through his work Democracy and Education. He put forward the perspective that schooling should be a laboratory for solving real-life problems (authentic problems). Problem Based Learning (PBL) Model has a general purpose to improve the skills of inquiry and problem-solving skills, behavior and social skills according to the role of adults, the skills to learn independently (Ageorges, Bacila, Poutot \& Blandin, 2014; Arends, 2012; Birgili, 2015; Efendioglu, 2015; Klegeris, Bahniwal \& Hurren; 2013; Skinner, Braunack-Mayer \& Winning, 2015; Purichia, 2015; Temel, 2014). The results of Yuzhi (2003) aims to teach chemistry analysis and analysis of playing a role in analytical chemistry through PBL. The results showed that students in the PBL group were much more successful in using laboratory equipment, resulting in solutions to problems, self-efficacy and generating 
theory. The result of Senocak, Taskesenligil and Sözbilir (2007) was compared to the achievement of pre-service basic science teacher in problem-based curriculum with people in the conventional curriculum.

Lecturer's Behavior

Leads students to the problem: Lecturer reviews the learning objectives, elaborates important logistical requirements and motivates students to engage in problem-solving activities.

Organizing students to learn: Lecturer helps students to define and organize learning tasks that are related to the problem.

Assisting the independent and group investigations: Lecturer encourages students to get the right information, conducts experiments and provides explanations and solutions.

Developing and presenting artifacts and exhibits: Lecturer assists students in planning and preparing appropriate artifacts and exhibits such as reports, video recordings and models. Lecturer helps students to present toward others.

Analyze and evaluate the problem-solving process: Lecturer helps students to reflect on their investigations and the processes they used.

Table 1. Problem Based Learning (PBL) Model Syntax

The results showed that PBL was effectively increase knowledge about gas, positive attitude toward chemistry, self-learning development, and critical thinking. The syntax of the PBL model is in Table 1 below.

The problem-based learning model still has some obstacles to be overcome if research wants to use it more widely. One of the obstacles is that PBL model is less suitable for large information coverage or basic knowledge and some lecturers do not encourage their use (Arends, 2012). According to Birgili (2015) study found that learning models could improve the critical thinking skills of learners with procedural problem-solving activities. The results suggest for follow-up research by providing more systematic activities, so learners can remember the steps during the problem to solve their critical thinking. The result of meta-analysis by Batdi (2014) toward the result of research since 2006 until 2013 shows that the learning of Problem Based Learning (PBL) is effective in learning to trained students' attitude. Other findings are 1) the learning environment needs to be considered further, so students need to understand the problem-based learning model and master the concept first, 2) the problem based learning model has not shown ability to train critical thinking skills maximally.

The results of the study by Zhou, Huang and Tian (2013) showed that the problem-based learning model could improve the critical thinking skills of learners in chemistry experiments. Problem-based learning model can provide real problems for learners who can improve their thinking and communication skills. Several recommendations for follow-up research include: 1) research is still needed on more varied models and methods to support the PBL model in enhancing the critical thinking skills of learners; 2) the provision of experimental time in the laboratory is still indispensable in supporting the implementation of the problem-based learning model.

The results of Sasser (2014) study found that the structure in PBLs is not a significant factor related to self-efficacy of teaching science. This is reinforced by Mataka and Kowalske (2015) finding that PBL is one of the student-centered learning strategies, in which students are given a big role in their own learning, therefore this role transfer may need more time for adaptation into student learning styles. The results of the study on the above PBL model indicate the importance of innovation on the PBL model to improve critical thinking skills and self-efficacy of pre-service chemistry teacher.

\subsubsection{Inquiry Model}

In summary, the inquiry model has several advantages: 1) improving students' learning motivation, 2) giving students opportunities to think carefully about ideas, problems, and questions 3) developing the skills and abilities that are necessary for working and daily life in the $21^{\text {st }}$ century, 4) improving thinking skills, providing opportunities for students to participate fully which will increase their curiosity both 
inside and outside the classroom (Gerald, 2011; Opara \& Oguzor, 2011). The syntax of the inquiry model is in Table 2.

\section{Stages of Learning Activities}

Formulating problem: Lecturer guides the student to identify the problem and to clarify the written problem on the board. Lecturer divides students into groups

Formulating hypotheses: Lecturer gives students the opportunity to express opinions in the form of hypotheses. The lecturer guides the student in determining the relevant hypothesis to the problem and prioritizes which hypothesis is the priority of the inquiry.

Collecting data: by experimenting: The lecturer guides students to get information through experiment.

Analyzing the experiment results: The lecturer guides the students to analyze the experimental data.

Making a conclusion: The lecturer guides students in making conclusions.

Table 2. Inquiry Model Syntax

Several studies have shown that the inquiry model can improve the critical thinking and scientific skills of learners (Alkan, 2016, Scott, 2013). The results of the research above shows that the inquiry learning model can improve critical thinking skills, but still has some weaknesses in its implementation. The results of Kazempour (2013) study found that the inquiry model can improve critical thinking skills especially in the learners' recognition and judgment indicators, but it could not improve the indicator of students' deductive thinking skills. The result of Alkan (2016) research can develop inquiry-based experimental learning model with the main purpose to improve learning result and scientific process skill of pre-service chemistry teacher. The sample in this study was 40 pre-service chemistry teachers in Chemistry Education of Hacettepe University. The results of the study by Alkan (2016) showed an increase in learning outcomes and significant scientific process skills. However, the implementation of inquiry-based experiment model developed by Alkan (2016) still requires improvements in the investigation activities with more varied material contents so that students have enough supplies when they become chemistry lecturers.

The results of the study by Scott (2013) that developed an inquiry learning model with a sample of pre-service natural science teachers found that the inquiry learning model can improve thinking skills, solve problems faced, content comprehension, and self-efficacy possessed by the pre-service natural science teachers. Weaknesses and recommendations on the research are 1) the absence of the experimental activities optimization in various laboratories and the need to increase investigation activities in the laboratory in each semester; 2) the mastery of knowledge about the natural science material needs to be considered in the learning when using the inquiry model, and 3) the need to improve self-efficacy owned by pre-service teachers in science learning especially with science-based process activities in laboratory investigations.

The results of the research by Scott (2013) and Alkan (2016) indicated the need for further research to improve the inquiry-based learning model by developing learning models that can improve critical thinking skills and self-efficacy of pre-service chemistry teacher through laboratory investigation activities, so students have provision in the process of learning chemistry in the classroom according to the $21^{\text {st }}$ century skills demands and to compete in the world of work in the globalization era. The results of the above studies show that PBL models and inquiry models still require modification and are developed to improve critical thinking skills and self-efficacy of pre-service chemistry teacher.

Preliminary research results and some related research results indicate an innovative chemistry-learning model needed to be able to trill critical thinking skills and self-efficacy according to the character of pre-service chemistry teacher in Indonesia. Learning models that can improve critical thinking skills and self-efficacy according to the pre-service chemistry teachers' character is Problem Based Learning (PBL) and Inquiry model. The strength and weakness of PBL and Inquiry models will be used as a basis in the design of chemistry learning models as shown in Table 3. 


\begin{tabular}{|c|c|}
\hline Learning & Weakness \\
\hline $\begin{array}{l}\text { Problem } \\
\text { Based } \\
\text { Learning } \\
\text { (PBL) }\end{array}$ & $\begin{array}{l}\text { 1. Birgili research results (2015) suggested further research by providing more systematic activities, so } \\
\text { learners can remember the steps during the problem solving to their critical thinking. } \\
\text { 2. The results of meta-analysis by Batdi (2014) on the results of the } 2006 \text { to } 2013 \text { study of Problem } \\
\text { Based Learning (PBL) showed that a) the learning environment needs to be considered further, so } \\
\text { students need to understand the problem-based learning model and master the concept first, } \\
\text { b) problem based learning model has not shown capability to train critical thinking skills } \\
\text { maximally. } \\
\text { 3. Results of research by Zhou et al. (2013) on PBL models provided recommendations to follow-up } \\
\text { research include: a) research is still needed on more varied models and methods to support the } \\
\text { PBL model in enhancing the learners' critical thinking skills; b) the provision of experimental time } \\
\text { in the laboratory is still indispensable in supporting the implementation of the problem-based } \\
\text { learning model. } \\
\text { 4. The results of Sasser (2014) study found that the structure in PBL is not a significant factor } \\
\text { related to self-efficacy in teaching science. This is reinforced by Mataka and Kowalske (2015) } \\
\text { findings, which stated that PBL is one of the student-centered learning strategies, in which } \\
\text { students are given a big role in their own learning, so this role transfer may need more time for } \\
\text { adaptation into the students' learning style. }\end{array}$ \\
\hline & $\begin{array}{l}\text { 1. The results of Kazempour (2013) study found that the Inquiry learning model can improve critical } \\
\text { thinking skills especially in the recognition and judgment indicators of the learners, but cannot } \\
\text { improve the indicator of students' deductive thinking skills. } \\
\text { 2. The results of the Alkan (2016) study on the implementation of experiment-based inquiry activity } \\
\text { (Inquiry) developed by Alkan still require improvements in the investigation activities with more } \\
\text { varied material contents so that students have enough supplies when they become chemistry } \\
\text { lecturers. } \\
\text { 3. The results of the research by Scott (2013) provided recommendations on the Inquiry learning } \\
\text { model research, they are 1) the lack of the experimental activities optimization in various } \\
\text { laboratories and the need to increase the investigation activities in the laboratory in each semester, } \\
\text { 2) the mastery of knowledge about natural science material need be considered in learning when } \\
\text { using the Inquiry model, and 3) the need to improve the self-efficacy of pre-service teachers in } \\
\text { science learning especially with science-based activities in laboratory investigations. }\end{array}$ \\
\hline
\end{tabular}

Table 3. The strength and weakness of PBL and Inquiry models

The results of the above studies indicate that innovations from the PBL and Inquiry models are specifically developed to improve critical thinking skill and self-efficacy of pre-service chemistry teachers. The science-learning model that will be developed to improve the critical thinking skill and self-efficacy refers to the flow of the problem-solving process from John Dewey.

\section{Discussions}

\subsection{Characteristics of Learning Models that are Developed to Improve Critical Thinking Skills and Self-Efficacy}

The characteristic of the Scientific Critical Thinking (SCT) learning model emphasizes a scientific approach. Methods that must be mastered by students and lecturers are in the form of methods of discussion, presentation, and experiment. The learning process in the developed learning model contains the components of the SCT model. The Characteristics of Scientific Activities in the experiment is supported by the existence of a Critical Thinking Task that is designed specially to improve the critical thinking skills and self-efficacy of pre-service chemistry teacher. In addition, the source integration of self-efficacy which includes enactive mastery experience, vicarious experience, verbal persuasion, and physiological and affective states during the learning is expected to improve the self-efficacy of pre-service chemistry teachers. The materials that can be used in Scientific Critical Thinking (SCT) learning are chemistry materials that can be implemented in real laboratory or virtual laboratory experiments.

There are at least four distinctive features (characteristics) of the learning model that can be used to achieve the learning objectives: 1) the logical theoretical rationale of the design, 2) the learning objectives 
of the developed model, 3) the teaching behavior that is necessary to accomplish the learning, and 4) the learning environment that is necessary to achieve the learning objectives (Arends, 2012).

\subsubsection{The Logical Theoretical Rationale of its Design}

The chemistry learning model that will be developed to improve critical thinking skills and self-efficacy of pre-service chemistry teacher refers to the flow of the problem-solving process from John Dewey. The developed learning model refers to the problem-solving process proposed by John Dewey (1910) suggests that problem-solving is a deliberate process that is consisted of the following steps: understanding the problem, identifying the nature of the problem, developing the hypothesis to solve the problem, testing different hypotheses, and choosing the most appropriate alternative between the hypotheses (Moreno, 2010). The flow of critical thinking process from John Dewey is supported by theories of learning; they are cognitive-social constructivist theory, cognitive learning theory, behavioral learning theory, and motivational learning theory.

The chemistry-learning model that was developed to improve critical thinking skills and self-efficacy of pre-service chemistry teacher referred to the flow of the problem-solving process from John Dewey. The developed learning model referred to the problem-solving process proposed by John Dewey (1910) suggested that problem-solving is a deliberate process consisting of the following steps: understanding the problem, identifying the nature of the problem, developing the hypothesis to solve the problem, testing different hypotheses, and choosing the most appropriate alternative between the hypotheses (Moreno, 2010). The flow of critical thinking process from John Dewey is supported by theories of learning, namely cognitive-social constructivist theory, cognitive learning theory, behavioral learning theory, and motivational learning theory. The rationality of each phase sequence in the developed learning model is studied based on the researcher's argument, theoretical studies, and empirical studies are presented in Figure 1.

The rationality of each phase sequence in the developed learning model is studied based on the researcher's argument, theoretical studies, and empirical studies in Figure 1 which is described as follows. The first phase is student orientation. At the beginning of the learning process, lecturer has to convey the purpose of learning, provide the learning direction, and the assessment of critical thinking skills and self-efficacy. Based on the theory of ARCS (Attention, Relevance, Confidence, and Satisfaction) to arise curiosity and interest in learning then the student must pay attention (Keller, 2010) and self-efficacy; a person's belief that he or she can succeed in performing a given task (Moreno, 2010). Motivation theory is reinforced by the results of research that motivation gives effect to success in individual and critical thinking (OECD, 2013; 2015). Lecturers divide students into heterogeneous groups (3-4 students) and give worksheet related to the task of critical thinking skills. The formation of heterogeneous groups is based on social constructivism by Vygotsky, that learners share individual perspectives with others to build mutual understanding that is not possible to be building individually (Moreno, 2010). Face-to-face social interaction allows students to share alternative views or ideas, help students see ideas differently. Lecturers provide worksheet with the task to train critical thinking and self-efficacy skills based on Dewey's perspective (1916), schools should become laboratories for real-life problem solving (Arends, 2012). Reinforced by a top-down process; students start with complex problems to be solved and then solve or find (with the help of lecturers) the necessary basic skills (Slavin, 2011). This condition aims to facilitate the students in processing the concept that will be learned in the learning because the beginning of learning concept will be more remembered by the students. This is particularly appropriate because critical thinking and self-efficacy skills need to be introduced at the beginning of the lesson based on the theory of primacy effect; the tendency for items that appear at the beginning of a list is easier to remember than other items (Slavin, 2011). Based on the study of rationality above, the first phase in the learning model developed is student orientation. 
Goal: To produce a learning model that valid, practically, and effective to improve the critical thinking skills and selfefficacy of pre-service chemistry teacher.

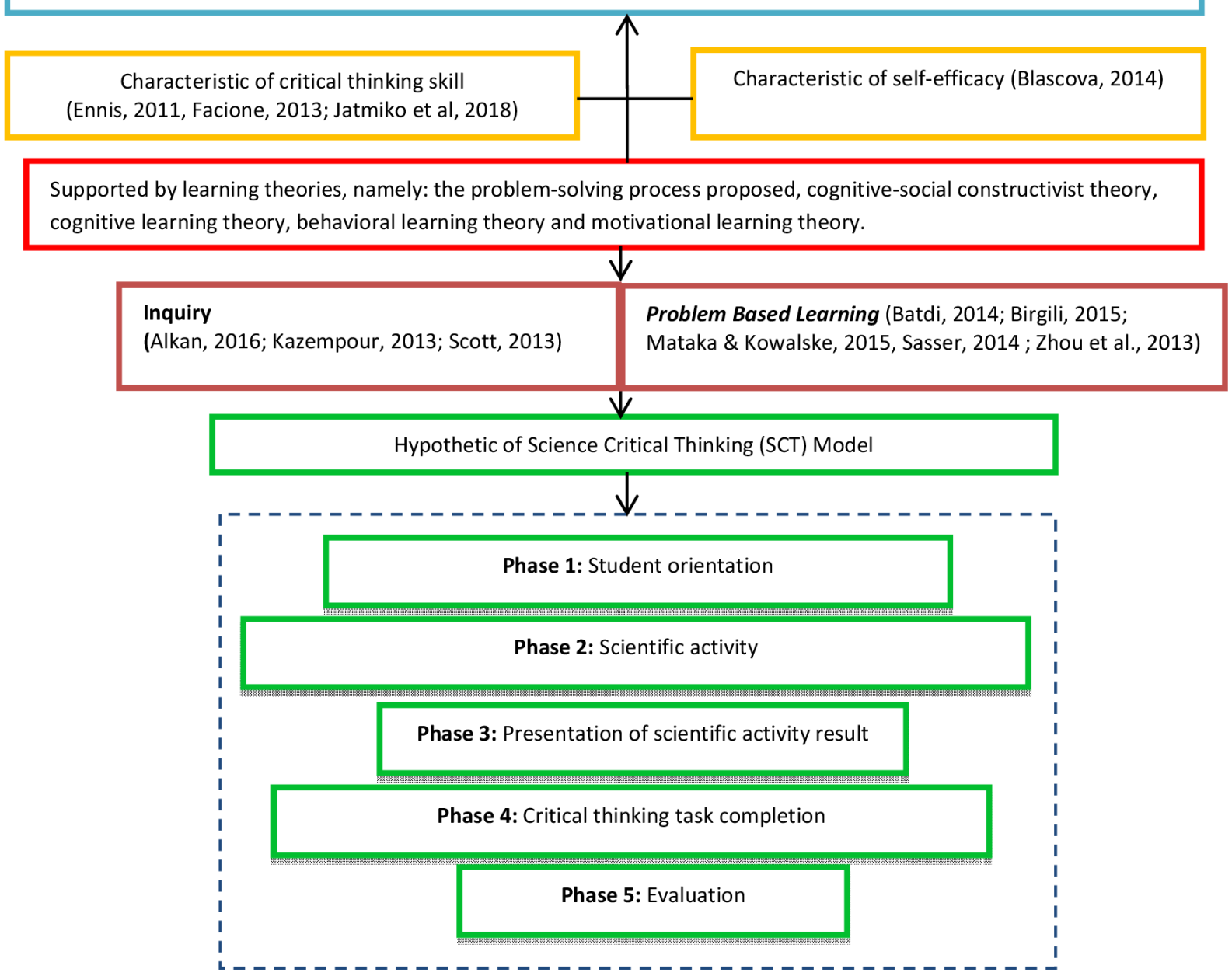

Figure 1. Rationality of the Developed a Scientific Critical Thinking (SCT) Model

The second phase is scientific activity. Students carry out experiments to train critical thinking skills and in still self-efficacy. Attention, the learner needs to attend to relevant information from the model to be able to learn from the model (Bandura, 1977) dan self-efficacy; a person's belief that he or she can succeed in performing a given task (Moreno, 2010). The results of Alkan (2016) study on the implementation of experimental learning-based experimental model (Inquiry) developed by Alkan still require improvements in the investigation activities with more varied material contents so that students have enough supplies when they become chemistry lecturers. Therefore, every student has a responsibility in obtaining information. Information is obtained through the skills of the science process. It is based on cognitive constructivist theory by Piaget $(1954,1963)$, any student of any age actively involved in the process of obtaining information and constructing their own knowledge (Arends, 2012). The lecturer guides the students to complete the task by conducting an experiment as an effort to train critical thinking skills and in still self-efficacy based on social constructivist theory by Vygotsky, which has two main implications: 1) social learning; students learn through interaction with more capable adults and peers; 2) Zone of Proximal Development (ZPD); students learn the best concept when the concept is in their nearest development zone (Slavin, 2011). The results of the study by Scott (2013) provided recommendations on Inquiry learning model research, namely 1) the absence of experimental activities optimization in various laboratories and inquiry activities in the laboratory need to be increased in each semester, 2) the mastery of natural science knowledge needs to be considered in learning while using the Inquiry model, and 3) the need to improve the self-efficacy of pre-service teachers in science learning especially with science-based activities in laboratory investigations. Therefore, the second phase focuses on scientific activities to train critical thinking skills and self-efficacy of pre-service chemistry teacher. Based on the study of argument, 
theory, and empirical it is rational if the second phase in the developed learning model is a scientific activity.

The third phase is the Presentation of Scientific Activities. Lecturers guide students to internalize their concept, critical thinking skills and self-efficacy through presentation activities. Supported by theory of 1) self-efficacy; a person's belief that he or she can succeed in performing a given task (Moreno, 2010), 2) retention, the learner needs to remember the observed behavior in order to be able to imitate it in the future (Bandura, 1977). The results of meta-analysis by Batdi (2014) on the results of 2006 to 2013 study of Problem Based Learning (PBL) showed that a) learning environment needs to be paid more attention, and students need to understand the problem-based learning model and initial concept first, b) problem model based learning has not shown its' ability to train critical thinking skills maximally. Students must prepare the results of scientific activities. Based on social constructivist theory by Vygotsky, the cognitive apprenticeship, the process by which a student then becomes an expert in his interaction with an expert, a person or a higher-knowledge peer (Slavin, 2011). Multi-representation is required in the process. Dual coding theory; the information conveyed visually and verbally is better than information that is only provided in one-way (Slavin, 2011). Internalization is the process of deepening the critical thinking skill and students' self-efficacy that students have gained by repetition. Results of research by Zhou et al (2013) in the PBL model provided suggestions for further research that research on the models and methods, which are more varied, is needed to support the PBL model in improving the students' critical thinking skill of learners. In accordance with cognitive constructivist theory, that is information-level theory; People stimulate at different levels of mental state and will only store information that has been found to be the most serious and profound (Slavin, 2011). The results showed that students who process information seriously and earnestly had better $\mathrm{r}$ memory than those who did not (Slavin, 2011). Based on the study, theory, and empirical which is used, so it is rational that the third stage in the developed learning model is the scientific activity result presentation.

The fourth phase is the Settlement of Critical Thinking Tasks. Lecturers provide follow-up tasks in the form of Critical Thinking Tasks that must be solved individually as a stage to improve the critical thinking skill that they have already had and improve students' self-efficacy. In this activity, the students are expected to be more able to improve their self-efficacy and must have self-regulation in critical thinking for new problem. Supported by the theories of 1) self-efficacy; a person's belief that he or she can succeed in performing a given task (Moreno, 2010), 2) self-regulated learning, the ability to control all aspects of one's learning, from advance planning to how one evaluates performance afterward (Moreno, 2010), 3) production, the learner needs to convert the mental representations created during encoding to motor activity (Bandura, 1977). Students are expected to be able to transfer the knowledge they have acquired to new problems. In accordance with the theory of positive transfer occurs when using what was learned in the past facilitates learning something new or solving a new problem (Moreno, 2010) and scaffolding; students should be given complex, difficult, and realistic tasks and then given sufficient help to solve these tasks (Slavin, 2011). According to Birgili (2015) research results suggested further research by providing more systematic activities, so learners can remember the steps during the problem to solve their critical thinking. The results of Sasser (2014) study found that the structure in PBL is not a significant factor related to self-efficacy of teaching science. This is reinforced by Mataka and Kowalske (2015) findings, which stated that PBL is one of the student-centered learning strategies, in which students are given a big role in their own learning, so this role transfer may need more time for adaptation into the students' learning style. Based on the study of argument, theory, and empirical, it is rational if the fourth phase in the learning model developed is the critical thinking task completion.

The fifth phase is Evaluation. Students evaluate processes and outcomes in the completion of their Critical Thinking Task and self-efficacy. During this process, students must also be able to organize and assess themselves and others. This view is in accordance with self-efficacy; a person's belief that he or she can succeed in performing a given task (Moreno, 2010), self-evaluation, judging if the outcome of one's actions or strategies is acceptable or unacceptable (Moreno, 2010) and an individual's cognition 
about his/her cognition or "knowing about knowing" (Moreno, 2010). The lecturer guides students to evaluate the process and outcomes in the completion of the Critical Thinking Task and self-efficacy. The results showed that the lecturer need to evaluate the inquiry process that has been done by the students, it is an important component, without any feedback it will only obtained a little knowledge (Arends, 2012) and the importance of metacognitive implementation in critical thinking process. Lecturers give praise or appreciation for collaborative group achievements. In every correct action during the evaluation, it is also required praise immediately so that students are more enthusiastic and motivated in learning critical thinking. Praise refers to the clear performance (contingent praise) of the gift is determined by the performance of the student and the well-defined behavior (Slavin, 2011). Lecturers provide advanced tasks/projects to deepen concepts, collaborative solving skill, science process skill, creativity, and confidence. In accordance with motivation theory, learners need to be motivated to learn from the model and to reproduce what they learned (Bandura, 1977) and last effects; the tendency for things that appear at the end is easier to be remembered than other items (Slavin, 2011). Based on the study of argument, theory, and empirical, it is rational if the fifth phase in the learning model developed is evaluation.

Syntax is the steps that should be included in the lesson plan and the steps to be followed when the lecturer implements the learning model in the classroom. The syntax of learning model has 5 phases; they are 1) student orientation; 2) scientific activity; 3) presentation of scientific activity result; 4) critical thinking task completion; and 5) evaluation. Teaching behavior which is needed in order to make the learning can be done through the learning environment management with a Scientific Critical Thinking (SCT) model which focus on scientific activities and social skills, mutual respect and cooperation, use resources who have capability to train critical thinking skill and self-efficacy for pre-service chemistry teacher. Hypothetic SCT learning model should be tested to fulfill the validity, practicality, and effectiveness aspects to improve pre-service chemistry teachers' critical thinking skill and self-efficacy.

This study are supported by the previous studies results (Castro, Guerra, Brito \& Chávez, 2018; Erika, Prahani, Supardi \& Tukiran, 2018; Jatmiko et al., 2018; Lopez \& Campoverde, 2018; Madeali \& Prahani, 2018; Limatahu, Suyatno, Wasis, \& Prahani, 2018; Prahani, Winata \& Yuanita 2015; Prahani, Limatahu, Winata, Yuanita \& Nur, 2016; Prahani, Nur, Yuanita \& Limatahu, 2016; Prahani et al., 2018; Purwaningsih, Suyatno, Wasis, \& Prahani, 2018; Sudiarman, Soegimin \& Susantini, 2015; Sunarti, Wasis, Madlazim, Suyidno \& Prahani, 2018; Suyidno, Nur, Yuanita \& Prahani, 2017; Suyidno et al., 2018; Yasir, Ibrahim \& Widodo, 2016) that the media, teaching materials, devices, and learning models of quality and feasible (meet the valid, practical, and effective aspects) can improve student learning outcomes.

\subsubsection{The Purpose of SCT Model Development}

The Scientific Critical Thinking (SCT) model is designed with the ultimate goal to train critical thinking skills and self-efficacy of pre-service chemistry teacher.

\subsubsection{Learning Behavior}

The management of the learning environment with the Scientific Critical Thinking (SCT) model focuses on scientific activities and social skills, mutual respect and cooperation, by using resources that are able to train critical thinking skills and self-efficacy of pre-service chemistry teacher, develop problem solving skills, science process skills, creativity, and communication skills.

\subsubsection{Learning Environment}

The Learning environment in Scientific Critical Thinking (SCT) model that is expected to improve the competence of the pre-service chemistry teacher is in Table 4. 


\section{Learning Environment}

Phase 1: Student Orientation

1. Lecturers should be able to motivate and provide positive expectations by explaining the importance of critical thinking skills and self-efficacy.

2. The lecturers should be able to divide the students in the group and provide the worksheets for the experiment.

Phase 2: Scientific activity

1. The lecturers should be able to guide the students in conducting the experiment.

2. Students should work together to optimize all their knowledge in designing and conducting experiments.

3. Skills of the science process will be dominant in the phase of scientific activity, so the lecturers must ensure that the students have been able to implement the science process skills in the experimental activities.

Phase 3: Presentation of Scientific Activities Result

1. Students communicate the results of scientific activities.

2. The lecturers should be able to guide the students to explore the students' scientific activities.

Phase 4: Completion of Critical Thinking Tasks

1. Lecturers should guide in the implementation of self-regulated learning.

2. Students should be able to improve their critical thinking skills and self-efficacy.

Phase 5: Evaluation

1. Evaluation that is done by the lecturers in the learning process will improve students' critical thinking skills and the students' concept understanding is confirmed by feedback so that students do not experience misconception.

2. Lecturers should be able to create a comfortable environment so that students are open to evaluate themselves about what they have gained.

Table 4. The Learning Environment in Each Phase of the SCT Learning Model Syntax

\subsection{Component of SCT Model}

The learning process in the developed learning model is contained in the components of the SCT model. According to Joyce et al. (2009), a good learning model should have 5 (five) major components in the model, they are: 1) syntax, 2) social systems, 3) reaction principles, 4) support systems, and 5) the impact of instructional and companion impact.

\subsubsection{Syntax}

The Scientific Critical Thinking (SCT) model has five-phase syntax; they are 1) student orientation, 2) scientific activity, 3) presentation of the scientific activities results, 4) completion of critical thinking tasks; and 5) evaluation.

\subsubsection{Social System}

Based on the syntax that has been compiled above, the suggested social system that states the role and relationship between lecturers and students are:

- Students are proactive in learning activities by contributing to critical thinking process and self-efficacy in groups.

- Lecturer acts as mentors, moderators, facilitators, consultants and mediators in the learning process to improve critical thinking and self-efficacy.

\subsubsection{Reaction Principles}

The reaction principle relates to how the lecturer looks at and treats the student, including the lecturer responding to questions, answers, responses, or what the student is doing. In the SCT model, the way lecturers pay attention and treat students should be like this:

- Lecturer motivates and reminds students to always emphasize critical thinking skills and self-efficacy. 
- The lecturer implements the strategy to improve students' self-efficacy with experiences (mastery experiences), vicarious experiences, verbal persuasion, and physiological and affective states in the process of implementing critical thinking skills.

- Lecturer provides feedback, praise, opportunity for students to ask questions, to argue, to criticize the learning process of chemistry so that students' self-efficacy and motivation can be increased.

\begin{tabular}{|c|c|c|}
\hline Lecturer Activity & Students Activity & Learning Achievement Indicators \\
\hline \multicolumn{3}{|l|}{ Phase 1: Students Orientation } \\
\hline $\begin{array}{l}\text { 1. The lecturer conveys the learning } \\
\text { objectives, provides instructional } \\
\text { direction, and assesses critical } \\
\text { thinking skills and self-efficacy. } \\
\text { 2. Lecturer divides students into } \\
\text { heterogeneous groups (3-4 } \\
\text { students) and divides the } \\
\text { worksheet. }\end{array}$ & $\begin{array}{l}\text { 1. Students pay attention to the } \\
\text { purpose of learning, direction } \\
\text { about learning, and assessment } \\
\text { of critical thinking skills and self- } \\
\text { efficacy delivered by lecturer. } \\
\text { 2. Students form heterogeneous } \\
\text { groups (3-4 students) and receive } \\
\text { worksheet that is provided by } \\
\text { lecturer }\end{array}$ & $\begin{array}{l}\text { Self-efficacy Indicator: Mastery } \\
\text { experiences and vicarious } \\
\text { experiences. }\end{array}$ \\
\hline \multicolumn{3}{|l|}{ Phase 2: Scientific Activity } \\
\hline $\begin{array}{l}\text { The lecturer guides students to carry } \\
\text { out experiments as an effort to train } \\
\text { critical thinking skills and instill self- } \\
\text { efficacy. }\end{array}$ & $\begin{array}{l}\text { Students carry out experiments to } \\
\text { train critical thinking skills and instill } \\
\text { self-efficacy. }\end{array}$ & $\begin{array}{l}\text { 1. Critical Thinking Indicators: } \\
\text { interpretation, analysis, } \\
\text { evaluation, and inference } \\
\text { 2. Self-efficacy indicators: Mastery } \\
\text { experiences, vicarious } \\
\text { experiences, social persuasions, } \\
\text { and physiological state. }\end{array}$ \\
\hline \multicolumn{3}{|c|}{ Phase 3: Presentation of Scientific Activities Result } \\
\hline $\begin{array}{l}\text { 1. Lecturer guides students to } \\
\text { present / communicate the } \\
\text { results of scientific activities to } \\
\text { classical / to other groups. } \\
\text { 2. The lecturer guides the students } \\
\text { to internalize the concept, critical } \\
\text { thinking skills and self-efficacy of } \\
\text { the students through the } \\
\text { presentation activities }\end{array}$ & $\begin{array}{l}\text { 1. Students present / communicate } \\
\text { the results of scientific activities } \\
\text { to classical / to other groups. } \\
\text { 2. Students internalize the concept, } \\
\text { critical thinking skills and self- } \\
\text { efficacy through presentation } \\
\text { activities. }\end{array}$ & $\begin{array}{l}\text { 1. Critical Thinking Indicators: } \\
\text { interpretation, analysis, } \\
\text { evaluation, and inference } \\
\text { 2. Self-efficacy indicators: Mastery } \\
\text { experiences, vicarious } \\
\text { experiences, social persuasions, } \\
\text { and physiological state. }\end{array}$ \\
\hline \multicolumn{3}{|c|}{ Phase 4: Completion of Critical Thinking Tasks } \\
\hline $\begin{array}{l}\text { Lecturer provides follow-up tasks in } \\
\text { the form of Critical Thinking Tasks } \\
\text { that must be solved individually as a } \\
\text { stage to improve the critical thinking } \\
\text { skills that they have already had and } \\
\text { improve their self-efficacy. }\end{array}$ & $\begin{array}{l}\text { Students undertake follow-up tasks } \\
\text { in the form of Critical Thinking } \\
\text { Tasks that must be solved } \\
\text { individually as a stage of improving } \\
\text { their critical thinking skills and } \\
\text { improving their self-efficacy. }\end{array}$ & $\begin{array}{l}\text { 1. Critical Thinking Indicators: } \\
\text { interpretation, analysis, } \\
\text { evaluation, and inference } \\
\text { 2. Self-efficacy indicators: Mastery } \\
\text { experiences, vicarious } \\
\text { experiences, social persuasions, } \\
\text { and physiological state. }\end{array}$ \\
\hline \multicolumn{3}{|l|}{ Phase 5: Evaluation } \\
\hline $\begin{array}{l}\text { The lecturer guides students to } \\
\text { evaluate the process and outcomes in } \\
\text { the completion of the Critical } \\
\text { Thinking Task and self-efficacy. }\end{array}$ & $\begin{array}{l}\text { Students evaluate processes and } \\
\text { outcomes in the completion of their } \\
\text { Critical Thinking Task and self- } \\
\text { efficacy. }\end{array}$ & $\begin{array}{l}\text { 1. Critical Thinking Indicators: } \\
\text { interpretation, analysis, } \\
\text { evaluation, and inference } \\
\text { 2. Self-efficacy indicators: Mastery } \\
\text { experiences, vicarious } \\
\text { experiences, social persuasions, } \\
\text { and physiological state. }\end{array}$ \\
\hline
\end{tabular}

Table 5. Lecturers and Students Activities SCT Learning Model 


\subsubsection{Support Systems}

The support systems of a learning model are all means, materials, and tools to apply the SCT model. The support systems in SCT model are:

- Learning tools refer to SCT model, for example: Syllabus, lesson plan unit, worksheet, Student Instruction, critical thinking skills evaluation instrument, and student self-efficacy assessment instrument.

- Chemistry experiments and materials in the laboratory.

- Learning media in the form of virtual laboratory and provided computer (for abstract chemistry material).

\subsubsection{Instructional Impact and Companion Impact}

One reference of the learning model is said to be effective, if the application is able to produce and achieve the main goal as an instructional impact of the learning. The instructional impacts of SCT model are:

- Students are able to improve critical thinking skills.

- Students are able to improve self-efficacy.

The companion impact is another learning result that is created from the learning process experienced by students with lecturer direction. The companion impacts of the SCT model are:

- Students' motivation and responses toward the learning are positive.

- Students can develop social skills and communication skills.

- Students can develop science process and problem-solving skills.

\section{Conclusions}

Researchers have designed the learning model based on theoretical and empirical studies; it formed learning model syntax as follows: 1) student orientation; 2) scientific activity; 3) presentation of the scientific activities result; 4) the completion of critical thinking tasks; and 5) evaluation. In this model, students are required to be pro-active in scientific activities to train critical thinking and self-efficacy skills so that the chemistry learning model developed is named as Scientific Critical Thinking (SCT) learning model. The SCT model is designed with the ultimate goal to train critical thinking skills and self-efficacy of pre-service chemistry teacher. Each phase of this learning model is expected to train critical thinking skills and self-efficacy of pre-service chemistry teacher. The limitation of this research is still in the development phase of hypothetical SCT model. Further research is necessary to prove that hypothetical SCT learning model is feasible by fulfilling the validity, practicality, and effectiveness aspects of improving critical thinking skills and self-efficacy of the pre-service chemistry teacher.

\section{Declaration of Conflicting Interests}

The authors declared no potential conflicts of interest with respect to the research, authorship, and/or publication of this article.

\section{Funding}

Thank you for the Ministry of Research and Technology of Higher Education and Lambung Mangkurat University authorities, which have supported this research.

\section{References}

Ageorges, P., Bacila, A., Poutot, G. \& Blandin, B. (2014). Some lessons from a 3-year experiment of problem based learning in physics in a French school of engineering. American Journal of Educational Research, 2(8), 564-567. https://doi.org/10.12691/education-2-8-1 
Alkan, F. (2016). Experiential learning: Its effects on achievement and scientific process skills. Journal of Turkish Science Education, 13(2), 15-26.

Arends, R.I. (2012). Learning to teach. New York: McGraw-Hill Companies, Inc.

Atabaki, M., Keshtiaray, N., \& Yarmohammadian, M.H. (2015). Scrutiny of critical thinking concept. International Education Studies, 8(3), 93-102. https://doi.org/10.5539/ies.v8n3p93

Bandura, A. (1977). Self-efficacy: Toward unifying theory of behavioral change. Psychological Review, 84(2), 191-215. https://doi.org/10.1037/0033-295X.84.2.191

Batdi, V. (2014). The effects of problem based learning approach on students' attitude levels: A metaanalysis. Educational Research and Reviews, 9(9), 272-276. https://doi.org/10.5897/ERR2014.1771

Birgili, B. (2015). Creative and critical thinking skills in problem-based learning environments. Journal of Gifted Education and Creativity, 2(2), 71-80. https://doi.org/10.18200/JGEDC.2015214253

Blascova, M. (2014). Influencing academic motivation, responsibility and creativity. Procedia - Social and Behavioral Sciences, 15(9), 415-425. https://doi.org/10.1016/j.sbspro.2014.12.399

Castro, A.M.T., Guerra, G.E.C., Brito, C.A.P., \& Chávez, T.G.A. (2018). Leisure activities for the development of creative intelligence in mathematical problem solving. Journal of Tecbnology and Science Education, 8(2), 126-131. https://doi.org/10.3926/jotse.412

Dewey, J. (1910). Science as subject-matter and as method. Science, 31(787), 121-127.

Dewey, J. (1916). Democracy and education. An Introduction to the philosophy of education. New York, NY: Free Press.

Efendioglu, A. (2015). Problem-based learning environment in basic computer course: Pre-service teachers' achievement and key factors for learning. Journal of International Education Research, 11(3), 205-222. https://doi.org/10.19030/jier.v11i3.9372

Ennis, R.H. (2011). Critical thinking: Reflection and perspective-Part I. Inquiry, 26(1), 4-18.

Erika, F., Prahani, B.K., Supardi, Z.A.I., \& Tukiran. (2018). The development of metacognition-based learning media for the industrial electronics field in a vocational high school. World Trans. on Engineering and Technology Education, 16(2), 179-185.

Facione, P.A. (2013). Critical thinking: What it is and why it counts. Insight Assessment, 1, 1-28.

Gerald, F.L. (2011). The twin purposes of guided inquiry: guiding student inquiry and evidence based practice. Scan, 30(1), 26-41.

Jatmiko, B., Prahani, K., Supardi, Z., Wicaksono, I., Erlina, N., Pandiangan, P. et al. (2018). The comparison of OR-IPA teaching model and problem based learning model effectiveness to improve critical thinking skills of pre-service physics teachers. Journal of Baltic Science Education, 17(2), 1-22.

Joyce, B., Weil, M., \& Calhoun, E. (2009). Models of teaching. New York: Pearson Education Inc.

Kalelioğlu, F., \& Gülbahar, Y. (2014). The effect of instructional techniques on critical thinking and critical thinking dispositions in online discussion. Educational Technology \& Society, 17(1), 248-258.

Kazempour, E. (2013). The effects of inquiry-based teaching on critical thinking of students. Journal of Social Issues \& Humanities, 1(3), 23-27.

Keller, M.J. (2010). Motivational design for learning and performance the ARCS model approach. USA: Springer. https://doi.org/10.1007/978-1-4419-1250-3 
Keenan, C.W., Kleinfelter, D.C., \& Wood, J.H. (1984). Kimia untuk Universitas, Jilid 1 (6 ${ }^{\text {th }}$ ed.). Jakarta: Erlangga.

Kivunja, C. (2015). Using de bono's six thinking hats model to teach critical thinking and problem solving skills essential for success in the $21^{\text {st }}$ century economy. Creative Education, 6, 380-391.

https://doi.org/10.4236/ce.2015.63037

Klegeris, A., Bahniwal, M., \& Hurren, H. (2013). Improvement in generic problem-solving abilities of students by use of tutor-less problem-based learning in a Large Classroom Setting. CBE-Life Science Education, 12, 73-79. https://doi.org/10.1187/cbe.12-06-0081

Kurbanoglu, N.I., \& Akim, A. (2010). The relationships between university students' chemistry laboratory anxiety, attitudes and self-efficacy beliefs. Australian Journal of Teacher Education, 35(8), 48-59. https://doi.org/10.14221/ajte.2010v35n8.4

Limatahu, I., Suyatno, S., Wasis, \& Prahani, B.K. (2018). The effectiveness of CCDSR learning model to improve skills of creating lesson plan and worksheet science process skills (SPS) for pre-service physics teacher. Journal Physics: Conference Series, 997(32), 1-7. https://doi.org/10.1088/1742-6596/997/1/012032

Lopez, J., \& Campoverde, J. (2018). Development of reading comprehension with graphic organizers for students with dyslexia. Journal of Technology and Science Education, 8(2), 105-114.

https://doi.org/10.3926/jotse.414

Madeali, H., \& Prahani, B.K. (2018). Development of multimedia learning based inquiry on vibration and wave material. Journal Physics: Conference Series, 997(29), 1-7. https:/ / doi.org/10.1088/17426596/997/1/012029

Mataka, L.M., \& Kowalske, M.G. (2015). The influence of PBL on students' self-efficacy beliefs in chemistry. Chem. Educ. Res. Pract., 16, 929-938. https://doi.org/10.1039/C5RP00099H

Moreno, R. (2010). Educational psychology. New York: Jhon Wiley \& Sonc, Inc.

Nieveen, N., McKenney, S., Gravemeijer, K., \& Van den Akker, J. (2007). Educational design research. New York: Routledge.

OECD. (2013). PIS A 2015 collaborative problem solving framework. OECD Publishing.

OECD. (2015). The experience of middle-income countries participating in PISA 2000-2015. PISA, World Bank. Washington, DC: OECD Publishing.

Opara, J.A., \& Oguzor, N.S. (2011). Inquiry instructional method and the school science currículum. Current Research Journal of Social Sciences, 3(3), 188-198.

Perpres. (2012). Peraturan Presiden Republik Indonesia Nomor 8 Tabun 2012 Tentang Kerangka Kualifikasi Nasional Indonesia. Jakarta: Kemdikbud.

Piaget, J. (1954). The construction of reality in the cild. New York: Basic Books.

Prahani, B.K., Winata, S.W., \& Yuanita, L. (2015). Pengembangan perangkat pembelajaran fisika model inkuiri terbimbing untuk melatihkan keterampilan penyelesaian masalah berbasis multi representasi siswa SMA. Jurnal Penelitian Pendidikan Sains, 4(2), 503-517.

Prahani, B.K., Limatahu, I., Winata, S.W., Yuanita, L., \& Nur, M. (2016). Effectiveness of physics learning material through guided inquiry model to improve student's problem solving skills based on multiple representation. International Journal of Education and Research, 4(12), 231-244.

Prahani, B.K., Nur, M., Yuanita, L., \& Limatahu, I. (2016). Validitas model pembelajaran group science learning: Pembelajaran inovatif di Indonesia. Vidbya Karya, 31(1), 72-80. 
Prahani, B.K., Suprapto, N., Suliyanah, Lestari, N.A., Jauhariyah, M.N.R, Admoko, S. et al. (2018). The effectiveness of collaborative problem based physics learning (CPBPL) model to improve student's selfconfidence on physics learning. Journal Physics: Conference Series, 997(08), 1-6. https://doi.org/10.1088/17426596/997/1/012008

Purichia, H. (2015). Problem-based learning: An inquiry approach. Interdisciplinary Journal of Problem-Based Learning, 9(1), 5

Purwaningsih, E., Suyatno, S., Wasis, W., \& Prahani, B.K. (2018). The effectiveness of Concept Mapping Content Representation Lesson Study (ComCoReLS) model to improve skills of Creating Physics Lesson Plan (CPLP) for pre-service physics teacher. Journal Physics: Conference Series, 997(22), 1-7. https://doi.org/10.1088/1742-6596/997/1/012022

Rusmansyah (2016). Profil keterampilan berpikir kritis dan self efficacy mahasiswa program studi pendidikan kimia. Banjarmasin: LP3M ULM.

Sasser, S.K. (2014). Effect of structure in problem based learning on science teaching efficacy beliefs and science content knowledge of elementary preservice teachers. Unpublished Dissertation. Southern Illinois University Carbondale.

Scott, H.S. (2013). Inquiry, efficacy and science education. Electronic Theses \& Dissertations. Georgia Southern University.

Senocak, G., Taskesenligil, Y., \& Sözbilir, M. (2007). A study on teaching gases to prospective primary science teachers through problem based learning. Research Science Education, 37, 279-290.

https://doi.org/10.1007/s11165-006-9026-5

Sirhan, G. (2007). Learning Difficulties in Chemistry: An Overview. Turkish Science Education, 4(2), 1.

Skinner, V.J., Braunack-Mayer, A., \& Winning, T.A. (2015). The purpose and value for students of PBL groups for learning. Interdisciplinary Journal of Problem-based Learning, 9(1), 1. https://doi.org/10.7771/15415015.1499

Slavin, E.R. (2011). Educational psychology: Theory and practice. Boston: Pearson.

Sudiarman, S., Soegimin, W.W. \& Susantini, E. (2015) Pengembangan perangkat pembelajaran fisika berbasis inkuiri terbimbing untuk melatihkan keterampilan proses sains dan meningkatkan hasil belajar pada topik suhu dan perubahannya. Jurnal Penelitian Pendidikan Sains, 4(2), 636-647.

Sunarti T., Wasis, Madlazim, Suyidno, \& Prahani, B.K. (2018). The effectiveness of CPI model to improve positive attitude toward science (PATS) for pre-service physics teacher. Journal Physics: Conference Series, 997(13), 1-7. https://doi.org/10.1088/1742-6596/997/1/012013

Suyidno, S., Nur, M., Yuanita, L., \& Prahani, B.K. (2017). Validity of creative responsibility based learning: An innovative physics learning to prepare the generation of creative and responsibility. Journal of Research \& Method in Education, 7(1), 56-61. https:/ / doi.org/10.9790/7388-0701025661

Suyidno, S., Nur, M., Yuanita, L., Prahani, B.K., \& Jatmiko, B. (2018). Effectiveness of creative responsibility based teaching (CRBT) model on basic physics learning to increase student's scientific creativity and responsibility. Journal of Baltic Science Education, 17(1), 136-151.

Tan, K.C.D., \& Treagust, D.F., (1999). Evaluating students' understanding of chemical bonding. School Science Review, 81(294), 75-84.

Tarhan, L., \& Sesen, B.A. (2013). Problem based learning in acids and bases: Learning achievements and students' beliefs. Journal of Baltic Science Education, 12(5), 565-578. 
Temel, S. (2014). The effects of problems based learning on pre service teachers's critical thinking dispotitions and perceptions of problems solving ability. South African Journal of Education, 34(1), 1-20. https://doi.org/10.15700/201412120936

Yasir, M., Ibrahim, M., \& Widodo, W. (2016). Pengembangan perangkat pembelajaran biologi berbasis metakognitif untuk melatihkan kejujuran siswa. Jurnal Penelitian Pendidikan Sains, 5(2), 1109-1015.

Yuzhi, W. (2003). Using problem based learning in teaching analytical chemistry. The China Papers, July, 18-32.

Zhou, Q., Huang, Q., \& Tian, Q. (2013). Developing students' critical thinking skills by task-based learning in chemistry experiment teaching. Creative Education, 4(12), 40-45.

https://doi.org/10.4236/ce.2013.412A1006

Published by OmniaScience (www.omniascience.com)

Journal of Technology and Science Education, 2019 (www.jotse.org)

\section{(c) $($ i) $(8)$}

Article's contents are provided on an Attribution-Non Commercial 4.0 Creative commons International License. Readers are allowed to copy, distribute and communicate article's contents, provided the author's and JOTSE journal's names are included. It must not be used for commercial purposes. To see the complete licence contents, please visit https://creativecommons.org/licenses/by-nc/4.0/. 